\title{
Community Economic Development Through Fisheries And Agriculture Food Diversification In Adonara Island
}

\author{
Hapsa Usman, Adrianus Amheka, Bernad Bowakh \\ \{hapsagemini1978@gmail.com, adrianus.amheka@gmail.com, bbowakh@gmail.com\} \\ Politeknik Negeri Kupang
}

\begin{abstract}
This study aims to inventory and identify the types of local food types based on agriculture and fisheries that have the potential to be used as tourism food products in supporting the tourism sector on the island of Adonara. The study sites included 8 subdistricts on Adonara Island, East Flores Regency Representations of coastal, lowland and highland areas. The number of 100 respondents who met the specified criteria was sampled. The results showed that the main raw material products in the coastal area were dominated by fishery products $(68.70 \%)$, in the plain areas by food crop products $(66.11 \%)$, while in the highlands by horticultural products $(63.13 \%)$. The nutritional content of most products is a source of carbohydrates $(42.06 \%)$. The average value added of processed food products is $41.64 \%$. Most respondents do not understand and apply good food production methods $(91.65 \%)$. Based on its promotion potential, several products can be developed to support nutrition improvement (38.25\%) and home industries of packaged food products as local food products supporting tourism on the island of Adonara $(61.75 \%)$
\end{abstract}

Keywords: crocessed food, diversification, Fisheries, Agriculture, supporting Tourism, Adonara Island

\section{Introduction}

Adonara Island is one of the islands in the East Flores Regency with an area of 509 $\mathrm{km}^{2}$, and the highest point is $1,676 \mathrm{~m}$. The island is bordered by the Flores Sea to the north, the Solor Strait to the south (separating from Solor Island), and the Lowotobi Strait to the west. Adonara Has eight districts with several economic potentials that are superior in several sectors including the agricultural sector and the fisheries sector. besides that Adonara is also known for its several beautiful tourist beaches including Ina Bura Beach, Watotena Beach, Mekko Beach, White Sand Beach and others.

Adonara Island is famous for its local food specialties. Abundant areas both on the vast coastline with so many fisheries, as well as in the highlands and the plains have large agricultural food supplies and are rich in natural potential, but have not been managed and developed in an optimal This study aims to inventory and identify the types of local food types based on agriculture and fisheries that have the potential to be used as tourism food products in supporting the tourism sector on the island of Adonara. 
The concept of local food development as one of the economic potential and production factors. In economics, Production Factors include natural resources or land, labor and capital. Based on these factors of production, an area can have advantages over other regions. An area has a comparative advantage if it has a production commodity that can be developed for regional development [1]

Food diversification or food production are both related to national food security policies. Policy efforts for food diversification have been carried out since the early 1960s to anticipate the need or demand for national food crops [2], a Presidential Instruction (Inpres) No. 14 of 1974 concerning the Efforts to Improve the People's Food Menu (UPMMR) was subsequently reaffirmed through Presidential Instruction No 20 of 1979 concerning UPMMR. The purpose of the issuance of the presidential instruction is to follow up efforts to diversify the types of food in order to improve the quality of nutrition of the people's food, both in quantity and quality. In 1996, Law No. 7 of 1996 concerning Food was issued which gave a mandate to realize national food security. Subsequently, Law No. 25 of 2000 concerning Propenas was also issued, which began to signal efforts to diversify food crops, both for consumption and production.

Food security is organized to meet basic human needs that provide benefits fairly and evenly based on independence, and do not conflict with community beliefs. Food security development is carried out in stages through a process of community empowerment to recognize potential abilities, problem solving opportunities, manage and utilize natural resources effectively, efficiently and sustainably. Embodiment of community empowerment in the context of food self-sufficiency, carried out through empowering the poor in areas that are vulnerable to food insecurity in rural areas. This food diversification includes aspects of production, consumption, marketing, and distribution. From the aspect of production, diversification means an expansion of the spectrum of food commodities, both in terms of expanding the use of resources, exploitation of commodities and the development of food commodity production. Therefore, from the aspect of production, diversification includes the notion of horizontal and vertical diversification. On the consumption side, food diversification includes behavioral aspects that are based on both economic considerations such as income and commodity prices, and non-economics such as habits, tastes and knowledge. The meeting between the production and consumption sectors is inseparable from the role of marketing and distribution of these food commodities. Likewise Suhardjo [3] states that food diversification basically includes three interdependent spheres of understanding, namely (1) diversification of food consumption, (2) diversification of food availability, and (3) diversification of food production.

Diversification of food consumption is related to the realization of resilience. food [3]. Based on Law No. 7 of 1996 concerning Food, the concept of implementing food diversification is in line with the concept of food security adopted from the definition of food security from the Food and Agricultural Organization (FAO). There are four main pillars needed to realize food security, namely: 1) Aspect of Food Availability, 2) Stability of Supplies, 3) Access to Supplies, 4) Aspect of Food Consumption Utilization) Based on the four pillars of food security above, the implementation of diversification of food consumption is expected to be able to support all aspects of food security. Through diversifying food consumption will provide consumption choices, according to income groups and local (regional) economic potential.Various local foods such as corn, sorghum, coconuts, cocoa, tuna, grouper and various types of fish and seaweed have prospects large enough to be developed on regional tourism icon icons and as other food substitutes to be processed into prestigious food. This paper aims to identify the potential of superior agriculture and fisheries and Analyze superior potential to be used as a 
product of food diversification to formulate the economic development of local food-based communities in supporting the tourism sector in the Adonara Region.

The availability of food per capita is statistically sufficient, does not guarantee that all households are fulfilled their nutritional needs, because food is not necessarily distributed evenly throughout the household, so it does not guarantee that all households are adequately met, both in quantity and quality, safe, equitable, affordable, and in accordance with the tastes (preferences) of individuals in the household. The development of diversification of local food processing is seen as strategic in supporting food security, especially related to aspects of promoting the availability of diverse foods, tackling nutritional problems and empowering the economic community (creation and development of productive economic enterprises). This study aims to inventory and identify the types of Adonara Island local processed food, as well as assess the potential for development in terms of availability of food sources from local resources, community empowerment, promotion, improvement of product competitiveness, improvement of community nutrition and productive economic efforts in food self-sufficiency efforts and support the Tourism Sector in Adonara Island, East Flores Regency [4]

\section{Methodology}

This research was conducted for approximately 5 months, starting from April to October 2019. The research site covered all of Adonara Island in East Flores Regency, East Nusa Tenggara Province. The research unit (respondent) was selected purposively, which fulfilled the criteria: owner / manager of food stalls, restaurants, canteens, and catering businesses; owner / manager of a home industry making food processed products for sale; and housewives who can usually make food processed products, both for their own consumption and for sale. Data collection is done by survey methods, interviews, observations and documentation of research objects [5]. A total of 100 respondents were interviewed representing 8 sub-districts in Adonara Island covering the coastal area of 37 respondents, medium lands 33 respondents and upland 30 respondents.

Table 1. Distribution of respondents by research area

\begin{tabular}{|c|l|l|l|l|}
\hline \multirow{2}{*}{ Number } & \multirow{2}{*}{ District } & Number of respondents / regions \\
\cline { 3 - 5 } & & littoral & Moderate Plains & highland \\
\hline 1. & Adonara & 4 & 2 & 3 \\
\hline 2. & West Adonara & 7 & 3 & 4 \\
\hline 3. & Middle adonara & 0 & 4 & 5 \\
\hline 4. & East Adonara & 9 & 3 & 3 \\
\hline 5. & Ile Boleng & 5 & 6 & 4 \\
\hline 6. & Kelubagolit & 0 & 7 & 5 \\
\hline 7. & Witihama & 5 & 5 & 4 \\
\hline 8. & Wotan Ulumado & 7 & 3 & 2 \\
\hline Jumlah & & 37 & 33 & 30 \\
\hline
\end{tabular}

Note: Kelubagolit Subdistrict and Central Adonara do not have Coastal Areas because they are located in the highlands. 
Raw material data and manufacturing additives (based on recipes for processing methods) are analyzed for nutritional content using the Online Computer System Software on Dietry Analysis (SODA) based on Food Composition List [6] and conversion of exchangers using the raw material (recipe) approach be used. By knowing the raw materials for making and processing (including conversion of nutritional changes during processing), it can be seen the nutritional content per 100 grams of its products.

Product added value is the value of the product minus the price of raw materials and donations of other materials. Percentage of added value is value added divided by the value of the product multiplied by $100 \%$. Data processing hygiene level is analyzed by applying good manufacturing practice / Good food production methods are understood and implemented (7). Assessment with a number system, with the assessment criteria include: 8-10 (good = almostto apply all), 5-7 (moderate $=$ some follow the rules), and 1- 4 (less $=$ a little - not at all apply). The data obtained were then tabulated and analyzed descriptively.

\section{Results And Discussion}

Potential Diversification of Local Processed Food Products Research results show that the distribution of processed food products is closely related to the potential availability of main raw materials (local food). The main raw material is the manufacture of processed products derived from at least $25 \%$ of agricultural products, according to one of the terms of agro-industry according to Soekartawi [7], in this case the intended agricultural product is local food (where the product is made) which is the largest part of the whole material raw processing.

Respondents in the coastal area covered most of the districts of East Adonara, West Adonara, Wotan Ulumado, Witihama and Ile Boleng. Most of them were processed food products made from fishery main raw materials $(68.70 \%)$, both sea and fresh water including fish Tuna, Grouper, Tuna, Tembang, Napoleon Cedro, mackerel, Stingray, anchovies, shellfish, squid, shrimp, crab, and Seaweed. Followed by the main raw materials of food crop products $(19.14 \%)$ include corn, sweet potato, breadfruit, cassava, sorgun, thatch, and rice; The main raw materials for horticultural products $(11.43 \%)$ include oranges, salak, coffee, cocoa, ginger and bananas; the main raw materials for estate crop products $(29.81 \%)$ include coconut and sugar cane; and the main raw material for livestock products (8.86\%), namely Chicken Eggs.

Respondents who were in the plains area covered part of the Adonara District, Central Adonara District and East Adonara District, most of them were found as main raw material processed food products $(61.11 \%)$ including rice, cassava, ordinary corn, beans green beans, kidney beans, sweet potatoes, breadfruit, taro, Horticultural products are ranked second $(27.77 \%)$ include bananas, mangoes, papaya, forest banana heart, kepok banana heart, moringa leaves, guava. Furthermore, fishery products $(8.56 \%)$ include Tuna and Tenggir fish, Tuna, Grouper; plantation crops $(9.78 \%)$ namely Coffee and Cocoa fruit and livestock (6.78\%) namely chicken meat.

Whereas in the highlands it covers parts of the Kelubagolit and Adonara sub-districts in the middle of processed food products which are mainly made from horticultural raw materials $66.67 \%$ including eggplant, mustard greens, carrots, soursop, ginger, ripe bananas, ripe bananas, young bananas, turmeric, rambutan, temulawak, ginger, turmeric, banana heart, orange. Other small parts come from fishery products $(11.11 \%)$, including milkfish, catfish; food crops $(5.56 \%)$, namely starfruit, cassava, bronze and sweet potato; plantation crops $(11.11 \%)$ namely Coconut, Cocoa, and Coffee, livestock (2.45\%) namely Chicken Eggs, Ducks, (2.78\%). Most 
of these food sources are easily available at the respondent's location, because most of them are cultivated as commodities developed in the area around which the processed food products are made. these products are very potential to be developed in an effort to empower the community, both in economic empowerment and food independence, because they are easy to obtain, easy to make, and easy to consume to meet their daily food needs.

Table 2. Distribution of total processed food products based on main nutrient content

\begin{tabular}{|c|l|r|r|}
\hline Number & Main Raw Material Sources & \multicolumn{2}{|c|}{ Number of Product Samples } \\
\hline 1. & Carbohydrate & 38 & 38 \\
\hline 2. & Protein & 25 & 25 \\
\hline 3. & Grease & 10 & 10 \\
\hline 4. & Vitamin & 13 & 13 \\
\hline 5. & Mineral & 14 & 14 \\
\hline Total & & 100 & 100 \\
\hline
\end{tabular}

Note: $\mathrm{n}=$ product sample, each respondent only takes one product sample

Most of the local processed food products of Adonara Island can be promoted as a home industry, as well as for household consumption in an effort to improve food consumption patterns to tackle nutritional problems and at the same time as a promotion of tourism products in support of the tourism sector on Adonara Island. If this potential is developed it is hoped that the village economy will continue to develop, the community is not malnourished and the agricultural sector which is a supporter of the main raw material providers will be affected positively. Several types of processed foodstuffs can also be developed as food catering businesses, houses / stalls / restaurants with a touch of an interesting way of serving (Table 3).

\begin{tabular}{|c|l|l|l|}
\hline Number & $\begin{array}{l}\text { Potential for Promotion and } \\
\text { Development }\end{array}$ & \multicolumn{2}{|c|}{ Number of Product Samples } \\
\hline 1. & $\begin{array}{l}\text { Food / beverage industry home product } \\
\text { as a tourism product }\end{array}$ & 34 & 34 \\
\hline 2. & $\begin{array}{l}\text { Restaurant, house / food stall, and } \\
\text { catering business }\end{array}$ & 26 & 26 \\
\hline 3. & $\begin{array}{l}\text { Households for tackling nutritional } \\
\text { problems }\end{array}$ & 40 & 40 \\
\hline Total & 100 & 100 \\
\hline
\end{tabular}

Note: $\mathrm{n}=$ product sample, each respondent only takes one product sample

From the results of this study, it was found that most of the home food packaging industry, restaurants, food stalls / restaurants, and catering businesses variety and collection of products and food menus are still very limited, especially those characterized by Adonara Island. Products that can be developed as a home food packaging industry are dry, semi-wet and liquid products that are processed and packaged (including labeling) for durability such as instant ginger, Soursop juice, Orange syrup, Papaya candied, Mango Candied,, shredded fish, pickles, carrot crackers, Fish Crackers, Sweet Potato crackers, and others. Products that can be developed as restaurant menus, home / food stalls and catering, especially foods that have distinctive names, food origin or use words from the Adonara language such as Bloma Chicken, Klesong,, Brown rice, Corn rice, Sei Fish, Fried Corn, Corn Bose, banana heart mixed papaya 
flower, Lodeh vegetable, squid satay, Tuna curry fish, anchovy vegetable tamarind, anchovy lawar, grilled tuna fish, broth, tamarind grouper, and others. While what can be promoted for the prevention and prevention of nutrition, adjusted nutrition problems faced by the Indonesian population today are lack of protein energy (PEM), iron nutrient anemia, and vitamin A deficiency such as cassava rice, corn rice, brown rice, green bean rice, porridge corn chicken, tuna fish brain, Aloe Vera cendol, Papaya flower ointment, Soursop juice, Red young coconut, salted egg (Chicken), and others. By adding a collection of local processed foods Adonara Island in the food menu at the business, there will be many choices. Aside from popularizing the food, it will also add to the image of catering businesses, home / food stalls and restaurants as well as tourism products at tourist attractions on the island of Adonara.

Application of Good Food Production Methods From observations and interviews in the field it is found that the application of good food production methods (CPMB) is still not widely understood or applied, so efforts are needed to socialize and conduct training so that the products produced are of good quality and guaranteed safety. As many as $91.65 \%$ of respondents had little or no understanding and applying (category lacking scores 1-4). Distribution of Respondents Based on the Implementation of CPMB can be seen in Table 4.

Table 4. Distribution of Respondents Based on the Application of Good Food Production Methods

\begin{tabular}{|l|l|l|}
\hline \multirow{2}{*}{ CPMB implementation } & \multicolumn{2}{|c|}{ Number of Product Samples } \\
\cline { 2 - 3 } & \multicolumn{1}{|c|}{$(\mathrm{n})$} & \multicolumn{1}{c|}{$(\%)$} \\
\hline Baik (skor 8-10) & 0 & 0 \\
\hline Sedang (skor 5 -7) & 6 & 6 \\
\hline Kurang (skor 1 - 4) & 94 & 94 \\
\hline Jumlah & 100 & 100 \\
\hline
\end{tabular}

Note: $\mathrm{n}=$ product sample, each respondent only takes one sample product score of 8-10 (good $=$ almost-to apply all the rules), a score of 5-7 (moderate = partially follows the rules), and a score of 1-4 (less = little - absolutely not implement)

Based on the calculation of the total costs incurred with the selling price of the product, the average value added product is $44.54 \%$. The highest added value of food processing products can be found in candied Corn Chips, Shredded Fish and Salted Sweet Potato Chips (111.14\% and $112.41 \%$ ), while the lowest added value can be seen from Pineapple Pineapple and Purple Sweet Potato Cake (26.64\% and $27.61 \%$ ). The possibility of increasing the value added of local processed food is very large because the raw materials are available in the local area, even if purchased is not too expensive. The development of diversification of local processed food products, will indirectly stimulate the production of raw materials

\section{Conclusion}

Adonara Island has the potential for diversification of local processed food products which are quite diverse. Diversity is determined by the location of the source of raw material. In coastal areas, the dominant source of raw materials is fishery products $(68.70 \%)$, whereas in the plains region is mostly derived from food crop products (66.11), while in the highlands most are horticultural products $(63.67 \%)$. The main nutritional content of Adonara Island local processed food products is carbohydrates $(41.64 \%)$. The average value added of processed food products 
is $41.64 \%$. Understanding and Application of good food production methods (CPMB) for most respondents $(91.65 \%)$ is relatively lacking. Potential promotion and product development are for home industry packaging food products $(38.25 \%)$, to support nutritional improvement $(35.75 \%)$, the rest can be developed as food catering, and menus at home / food stalls and restaurants $(26.18 \%)$ and support tourism.

\section{Recommendation}

To further develop the diversification of local processed food products in Adonara Island, efforts need to be made and synergized through: 1 . The action program of Desa Mandiri Pangan through accelerating the diversification of food and nutrition consumption. 2. Local food competitions at certain events such as Tourism Events and as a follow up to promote processed food products at exhibitions, snack menus and lunch / dinner at official meetings / meetings. 3 . Fostering home industry with a touch on improvement in process technology, quality, packaging, and aspects of food safety. 4. Fostering catering, restaurant and home / food stalls businesses, by improving the aesthetic of serving and security aspects through the application of good food production methods. 5. Partnership Collaboration in Cross-sectoral Synergistic Community Empowerment.

\section{Reference}

[1] Adisasmita, Rahardjo, Regional Development of Concepts and Theories. Yogyakarta. Graha Ilmu 2008

[2] Undang-undang No.7 Tahun 1996 Tentang Pangan. Presiden Republik Indonesia. Anonim. (2008)

[3] Nano Parwoto, Independence-Based Community Development and Empowerment Model to r, Journal of Organization and Management, 2012, 8 (2) 135-154

[4]Bapeda Province of East Nusa Tenggara. 2011.

[5] BPS, East Flores Regency in 2013 Numbers. Larantuka, Indonesia, 2013

[6] Singarimbun, M. dan Effendi, S. Metoda Penelitian Survey. LP3ES, Jakarta. 1983

[7] Daftar Komposisi Bahan Makanan. Direktorat Gizi, Departemen Kesehatan Republik Indonesia. Anonim. (1996).

[8] Cara Pengolahan/Produksi Yang Baik/Good Manufacturing Practice (GMP) Pada Produk Pengolahan Hasil Pertanian. Permentan No.35/Permentan/ OT.140.17./2008.

[9] Achmad S, Guidelines for the Implementation of the 2012 Food Security Agency Work and Budget Program, 2012

[10] Ishemat Soerianegara, Management of natural resources. Bogor Post Graduate IPB, 1977

[11] Gatot S. Hardono, Development Strategy for Local Food Diversification, 2014 